\title{
The Tourist Era in the City of Porto: Enchantment, Suspension and (Un)Sustainability
}

https://doi.org/10.21814/uminho.ed.51.6

Márcia Silva

Centro de Estudos de Comunicação e Sociedade, Instituto de Ciências Sociais, Universidade do Minho, Braga, Portugal https://orcid.org/0000-0003-3464-2194 marciasilva.formacao@gmail.com

Rita Ribeiro

Centro de Estudos de Comunicação e Sociedade, Instituto de Ciências Sociais, Universidade do Minho, Braga, Portugal https://orcid.org/0000-0002-2330-1696

rmgr@ics.uminho.pt

Emília Araújo

Centro de Estudos de Comunicação e Sociedade, Instituto de Ciências Sociais, Universidade do Minho, Braga, Portugal https://orcid.org/0000-0003-3600-3310 era@ics.uminho.pt

\section{Abstract}

This text explores some angles of touristic time in Porto and how it affects the passage of time in the city and the time experienced by its residents. This short journey back in time through Porto, an attempt is made to describe and reflect upon three main eras: that of a city enchanted by tourism, a time marked by fantasy, growth, and wonder; the decline of the city brought about by a drastic decrease in the number of tourists due 
to constraints imposed by the COVID-19 pandemic; and the city on hold, waiting for the pandemic to blow over and desperately awaiting the return of the hustle and bustle of tourism. The text discusses some of the implications of touristic time and how it can be less favourable to time experienced by people and employed by social and economic projects aiming for rapid tourist conversions. This conclusion is a common thread through studies conducted in tourism, leading to discussions about the (un)sustainability of voracious tourism, made even more pressing by the pandemic and the resulting future starting to materialise in terms of experiential tourism mobility and interaction.

\section{Keywords}

city, pandemic, Porto, time, tourism

\section{Introduction}

The city is a space-time filled with history, memory and projections of the future. Built-up over time, time also accumulates in the folds of a city, visible in its ability to produce expectations, structure and steer the lives of both people and things (Fortuna, 1999, 2009). This article is an observational analysis carried out to explore some of the implications and challenges of the touristification process of the city of Porto. A particular focus is placed on the erasure of living memories from locations that have been reconfigured and transformed and the intense historical "accident" caused by the capitalist overexploitation of times and places within the city, particularly from 2000 onwards. By the turn of the century, Porto, like many other cities, had established itself as having enormous touristic potential. Tourism became a significant focus, overlapping with the city's development as a transnational business centre and the land of cosmopolitan consumption. With tourism-related activities growing to industrial levels, recent years have seen an intense demand for infrastructures and locations to provide accommodation, restaurants, transport, recreational activities and cultural events (Costa, 2018).

What happened, in effect, was that Porto became an attractive tourist city thanks to its natural and cultural characteristics, in addition to its historical and geographical features (put simply, proximity to the airport and a port). An enchanting location thanks to the capacity of places and times to be enjoyed in endless combinations between pleasure and profit, the city has 
been stunned over the last few years by passengers, tourists and fortuitous consumers who have not been inclined to stay. An unforeseen event then came to alter this timeline of the city's overexploitation, the COVID-19 pandemic. These places became void of tourists, consumers of everything and/or nothing - a magical source of diverse profitability, and Porto Dot (Porto.) ${ }^{1}$ would wake up day after day to face the nightmare that was the pandemic. The erosion of interactions, exchanges and reciprocities upon which tourism feeds began to empty the city of its touristic charm. Since then, the depressed city has become a "Porto morto" (dead Porto), the most dystopian imagery painted by inhabitants and long-term residents who witnessed the flash of linear, overwhelming, totalising tourism activity in the city. This paper also aims to scrutinise tourist operations (un)sustainability based on capitalistic models of over-exploitation by investing in geographic mobility tourism. The analyses carried out and conclusions reached shall be based on records of observations made at various times over the past few years, at the most significant spatio-temporal reconfigurations encountered. By acknowledging space and time as phenomena produced by culture and society (Araújo, 2020) and using ethnographic information and photographic material produced on this itinerary, a brief journey through the city takes place in an attempt to retrieve various levels of time - from historical, social and subjective to experiential - and its effects on urban and tourist dynamics.

\section{The City, Tourism And Time}

An extraordinary aspect to consider when thinking about the time-tourism dyad is how tourism is defined by the ephemeral character of the experience it enables. Bauman (1998/1999, 2006/2007, 2007/2008) classified tourism as charmingly liquid, attractive; extraordinary activities are undertaken in ordinary everyday life. For him, along with other authors (Cohen, 1984; Urry, 1994, 2002, 2011), tourism has this compelling characteristic of cutting through banal time, allowing for different times and spaces to be enjoyed, deepening memory, culture and reflection, whether historically loaded or not. However, according to Harvey (2001, 2013, 2016), tourism has become even more central to modern societies because it provides a time and space to exorcise the tension continuously imposed by daily life. Tourism and the wide range of possibilities it provides throughout the year, in any number of places or spaces, is the space-time in which to savour the

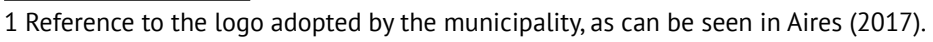


extraordinary, to press pause on routine and find an instant escape from the rhythm that petrifies our day to day lives.

Fluidity, variation and constant change are provided to tourists continuously, whereas they are merely passing features of ordinary societal life (Bauman, 2003/2006, 1995/2007). Cities followed this movement, particularly those whose "natural" qualities highlight the benefits of their consumption to even greater extents. These cities - and Porto is no exception - were consumed due to their instantaneous nature. They offered themselves up, all their times and spaces, in an ephemeral yet continuous way. With their commercial view trained on short-term results, cities were targeted with interventions and renovations based on an "urban entrepreneurship" logic. These changes were marked by the ennoblement and enhancement of the once degraded historic centres of cities on the one hand (Harvey, 2001, 2008), but which also threw cities into a deep, multileveled, multitemporal identity crisis on the other, in which times and spaces were manipulated, displaced, invented and fictionalised. Widespread interventions created a physical landscape and distinctive and aestheticised historical geography through speculative construction founded in the highly speculative relationship between public and private, all boiling down to "improving" a city's image, to the detriment of improving its living conditions (ways of life, schools, health services, security, etc.; Harvey, 2001, 2003, 2008). Many of these innovations and investments have been reproduced in numerous other European cities (Harvey, 2001), resulting in a "uniformity of the scenery, visible in the modernisation of old streets, applying colours and shapes to objects (goods) to make them attractive" (Lefebvre, 1970/2003, p. 30). As such, and as a result of strategies employed over the past 2 decades to appropriate and reappropriate space (Lefebvre, 1970/2003), cities have been Disneyfied (Harvey, 2001) and used as space-times of fleeting consumption.

Theoretical approaches converge on the idea of transforming historic cities into centres of consumption and entertainment, of sampling the intangible. They, therefore, become space-times of experiential hyper-consumption (Lipovetsky \& Charles, 2004; Zukin, 1995) overloaded with signs and images that increasingly transform elements within a city into mere objects of interest to the "tourist gaze" (Featherstone, 2007; Urry, 2002). In effect, what is being suggested is that tourism, the great metaphor for postmodernity (Bauman, 1998/1999), has appropriated and capitalised on the uniqueness, identity, memory and authenticity of space and time - the historical, the social, lived experience and life experienced. 
Some authors believe that historic cities and their environments have changed, never to return to what they once were (Wall \& Mathieson, 2006). As a result of losing the essence of spaces and times carried throughout history, cities fall into an identity limbo. In this limbo, a city no longer belongs to residents, who do not recognise their city or themselves within it, but also fails to be transferred to the tourists who consume it, experience and inhabit it at speed, whether more or less intensely. A manifestation of this limbo is the conversion of historic buildings, local commerce, and residents' dwellings into spaces designed to respond exclusively to the needs of tourists (Baptista \& Pujadas, 2000; Baptista et al., 2018; Boavida-Portugal \& Kastenholz, 2017; Law, 1992; Lipovetsky \& Charles, 2004; Pavel, 2017), therefore forcing residents to become clients and/or spectators of the city.

Perfectly aligned with the principles of capitalist exploitation of a city's space and time, the symbols of its identity - its emblems, memories, stories and heritage - are then placed on the market through tourist marketing, which is nothing more than an attempt to sell the city itself, in which visitors are promised experiences that cannibalise the city's identity and the ways of life within it. The critical view provided by several authors (Bruner, 1991; Jacques, 2003; Peixoto, 2003; Santos, 2007) emphasises the fact that culture thus becomes a strategy through which a brand image is designed. As part of this strategy, culture gains a highly competitive and communicational value, with a folklorisation of cultural practices and goods taking place and communities' social practices and traditions being staged to provide creations and exhibitions desired by tourists. According to some authors, this process corresponds to a staging of material and immaterial traces, which can be converted into virtual performances (Silva, 2000). As a result, places are going on to be considered "stages of performed sociability on which daily life is staged" (Peixoto, 2003, p. 221), transforming communities into a kind of theme park or tourist attraction (Collins, 2018; Hoffman, 2003).

The movement is all-encompassing, complete, libidinal because, as MacCannell (2020) suggests, "the causal forces at the heart of the tourism economy are entirely imaginary and symbolic" (p. 21). They objectify the city, personify and personalise it, filling it with humanity, and, at the same time, make it a (non)place of travel, of disconnection, ignorance and mystery. In this sense, the city takes on characteristics that make it ideal for tourism, as it becomes a place of pleasure, danger, occasion and threat that "fuels excitement and tiredness, handing around snacks on a tray" (Bauman, 1995/2007, p. 144). The instantaneous (Harvey, 2013) dominates the dialogue of the deaf taking place between those from the city and those not 
from it, like a powder that dissolves continuously in intoxicating fluids, even if harshly, or brutally, real for those whose daily lives are lived within the city as residents. The former sees the city as a Lebenswelt (lifeworld) aware of the depths of its history and memory. At the same time, the latter consumes the city at speed, in circumstances when tradition no longer calls for repetition, loyalty and the revival of what is done and has become "a product of nostalgic or folk consumption, a glimpse into the past, an object-trend ( ... ) of which the value limits itself to being purely aesthetic, emotional and playful" (Lipovetsky \& Charles, 2004, p. 94).

Extensive literature by Simmel (1997), Bachelard (1958/2005), Lefebvre (1986), Certeau (1994) and others (Fortuna, 1999, 2009; Pais, 2010) has shown the value of experiences undertaken by social subjects in appropriating a city's space-time, and space and time in general. A city open to the "tourist era" is open to tourists in an equally chronological, subjective and experiential sense. The amount of time a tourist spends in this space-time leaves its mark on the city's landscape, as does their perception and appreciation of time and space. From this perspective, the city, though invisibly, fragments into narratives made up of the memories, desires, frustrations, and illusions in the minds of the tourists themselves, who, in turn, have diverse sociodemographic profiles, trajectories, and social statutes, each of which impact on the way they experience time and place in a city (Cohen, 1984; Urry \& Crawshaw, 1995). Far from being an amorphous mass, tourists encompass a universe of experiences and choices made about the city: those that come back to a city, several times a year or year after year; those who come across it mid-trip to somewhere else; and those who make their way through the city in passing, only to return one day in the future, in a different phase of their own life (Cohen, 2001; Marujo, 2016; Urry, 1994, 1990/1996). As stated by Amir et al. (2014), tourists are attracted to a location for multiple reasons, from the cuisine to its landscapes, to the draw of visiting family and/or acquaintances and going in search of excitement (Elias \& Dunning, $1985 / 1992)$. What draws them to the city is a crucial factor to consider, as it is critical to determining the length of their stay. In effect, "everything a tourist observes and experiences in a destination can be considered an experience, be it of a behavioural nature, of perception, expressed or implied" (Marujo, 2016, p. 11). As such, a city that opens itself up to tourism opens itself to competitions aiming to increase the duration of tourist "stays" for the longer they stay, the higher the probability of consumption. 


\section{Methodology}

Several alternative methodologies could be employed to attempt to approach a city and time experienced within it in order to understand what Helena Pires (2014) calls "past-past (irreversible) times, but also memory (which does not take us back to past events rather, updates them), and the present-past-times of change and those that are long-lasting (qualitative time)" (p. 104). In effect, a city is made up of multiple, overlapping times, which are sometimes in tune with each other, sometimes at odds. It means that several epistemological and methodological decisions have been stumbled upon while studying the phenomenon of tourism in a city. These are especially applicable here, as this paper aims to assess how the city changes over time, reconfiguring itself in a different space-time - one that is potentially alien to some and familiar to others, resulting in diverse dynamics, among which are relationships of power and exploitation.

Specific methods of looking at the city and documenting its passage through time must be employed to apprehend the dynamics of the passage of historical time in multiple physical spaces, which is also, to some extent, the passage through the time of a voyeur or flaneur (as described by Simmel, 1997). Among others, and as explained by Agar (1985), participatory and direct observation presents itself as a particularly adequate methodology, as it allows for authors to experience places for themselves, gaining sensory views of space and time. After all, Pires (2008) states:

concrete spaces underpin urban landscapes, which are endowed with specific functions that are permanently being reconfigured due to social, political, economic and cultural transformations. In this perspective, to perceive a landscape is, therefore, to recognise the dominant paradigms that produce this viewable scenario, an image that should be observed as a form of symbolic domination, with a mediated gaze. (p. 761)

By employing this methodology, which positions the gaze employed as being from within the city's own space and time - that of its residents and their identities - it becomes possible to follow and register the construction and deconstruction processes that take place over time. A dynamic perspective is developed from photography and other records that leave their mark on the passing and changing of time. Still citing Pires (2014), 
observing the city's streets for a long time is a practice to which only tourists dedicate themselves, or those who, for a particular reason, decide to break with their daily routine to fix their gaze on details most often diluted amid an indistinguishable mass of signs. (p. 104)

Sure, this is a qualitative methodology (Flick, 2002), but it encompasses the intrinsic nature of a city lived experience, registered through photography. In fact, an increase in interest in visual methods has been registered in recent years (Heng, 2017). Particularly applicable to space studies, photography as a data collection technique is essential to understanding the changes in cities (Ferro, 2005). As an instrument of social investigation (Torre \& Ferro, 2016), photography can be understood as text that uses visual elements to communicate rather than words, transmitting information about a particular aspect of society (Smith, 2017).

The direct observation technique employed resulted in creating a repository of 1,261 photographs taken between May 2017 and October 2019, depicting gazes over the same places, multiplied over a timeframe of 3 years - 2017, 2018 and 2019. In 2020, the pandemic led to the need for further investigation, leading researchers back out into the field. The result made it possible to compare and record the transformations that have taken place in the territory over the years, once again fixing the camera's gaze on the same space-time, which includes streets and buildings. The gaze here is trained on the landscape, marked by a register established with a basis on previously outlined criteria, while also affected by impulses felt as a result of observations made.

The information gained through conversations, contact with residents, specifically in cafés, at demonstrations run by residents and at residents' meetings was brought together and presented alongside the photographs. Nine semi-structured interviews were conducted, guided by a script and audiorecorded, having gained the consent necessary to do so. Some excerpts from answers given to open questions provided in response to a questionnaire issued more recently are also used in this analysis.

The following text is an account of the time-travelling expedition embarked on by the authors, revisiting the places where time passes and erodes memory in multiple ways. These memories have been retrieved and recorded by the camera with two aims. The first is to reveal the contradictions and tensions brought to the city by the growth of tourism and its residents' resulting pain. The second is to point to Porto's potential as a city that, following 
the complete lack of tourism faced as a result of the pandemic, recognises the need for a long-term, sustainable plan for tourism to be drawn up in place of the short-term exploitation and extraction seen up until that point.

Thus, and as a result of the theoretical framework presented, the text that follows shall make three main stops in time: (a) the enchanted city, (b) the accelerated city, and (c) the waiting city. The first two are related to the researchers' and residents' view of the city that multiplied the spaces and times dedicated to tourism and tourists. The last refers to the city lying in wait for the pandemic to blow over, desperate for the movement and frenzy of the instantaneous nature of tourism, starting to come apart at the seams.

\section{The Enchanted City}

A process of urban renewal has been deployed in Porto over the last 2 decades, stimulated by the tourism development in the city. This renovation has resulted in tradition and authenticity mixing with modernity and innovation in what some authors consider a positive revival (Pereira, 2016), while others believe it has merely repeated the processes of folklorisation and Disneyfication of the city (Fernandes, 2011a, 2011b).

The tendency (and temptation) of framing it as enchanted by tourism is widespread throughout the city. Like so many others in Europe, it has been honed and transformed to meet the tourists and tourism alike needs. The photograph in Figure 1 expressively documents how tourism has donned the instantaneous city.

It has done so in passing but made sure it is "enchanted", providing "gifts" and the "Porto dot" logo painted in blue, like a heavenly metaphor of the city that (does not) exist. The first photograph (Figure 1) used to document this journey through time in the city has been entitled "towards the enchanted city". 

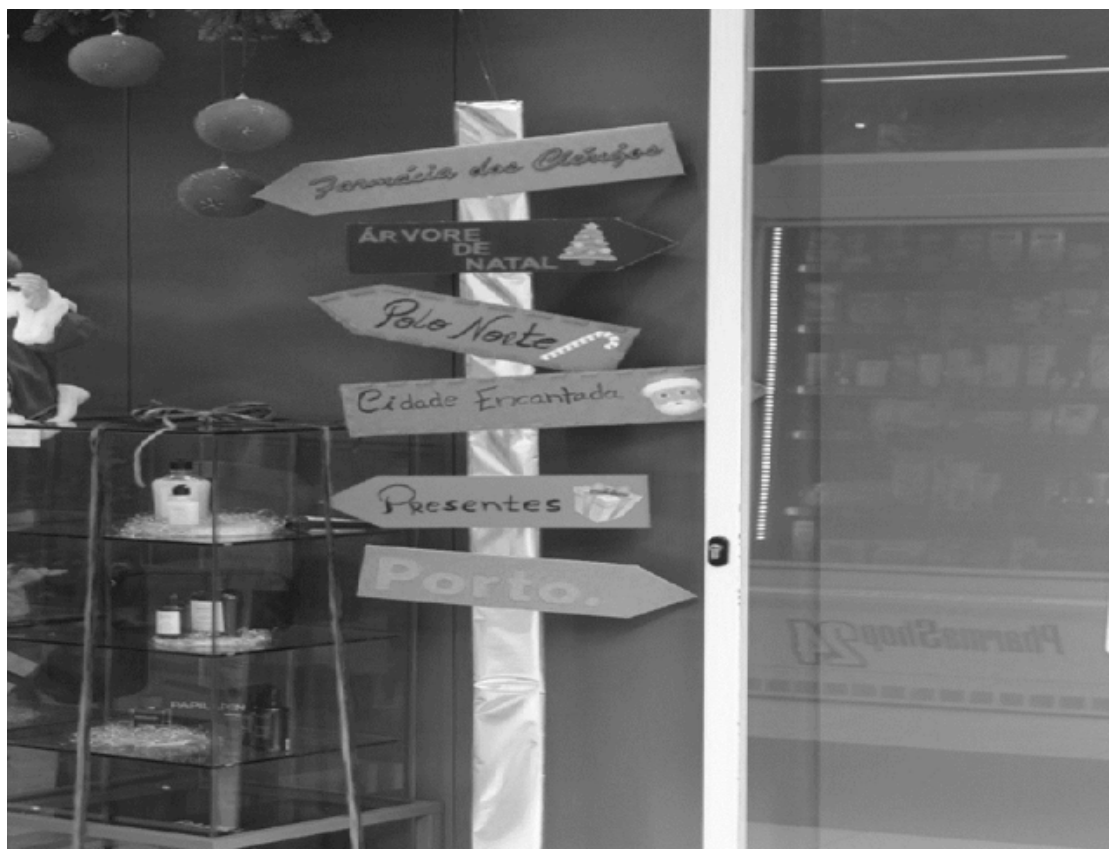

Figure 1 Towards the enchanted city (Christmas, 2018, on Rua dos Clérigos).

Credits. Márcia Silva.

This photographic record contains arrows pointing to the city of fruition and consumption, allowing for chronological time to be confronted continuously. Porto, this city that undresses and dresses back up for tourism, was explored several times. Therefore, markers of the passing time were rendered into memory using photography; old buildings, formerly shops, now converted into modern restaurants, bars, shops and temporary accommodation (Ramires et al., 2016).

In 2018, sun-bleached sheets of paper glued to the windows of Talho dos Clérigos butchers shop were peeling away, the tape struggling to hold them up, it too having been worn away by rays of sunlight. The information "closed for construction" (Figure 2) dictated the end of the butcher's, at least as it had been up until then.

By 2019, time had taken away the independent local shop, replacing it with the international chain Starbucks (Figure 3), a carbon copy found replicated in many other locations around our globalised world. 


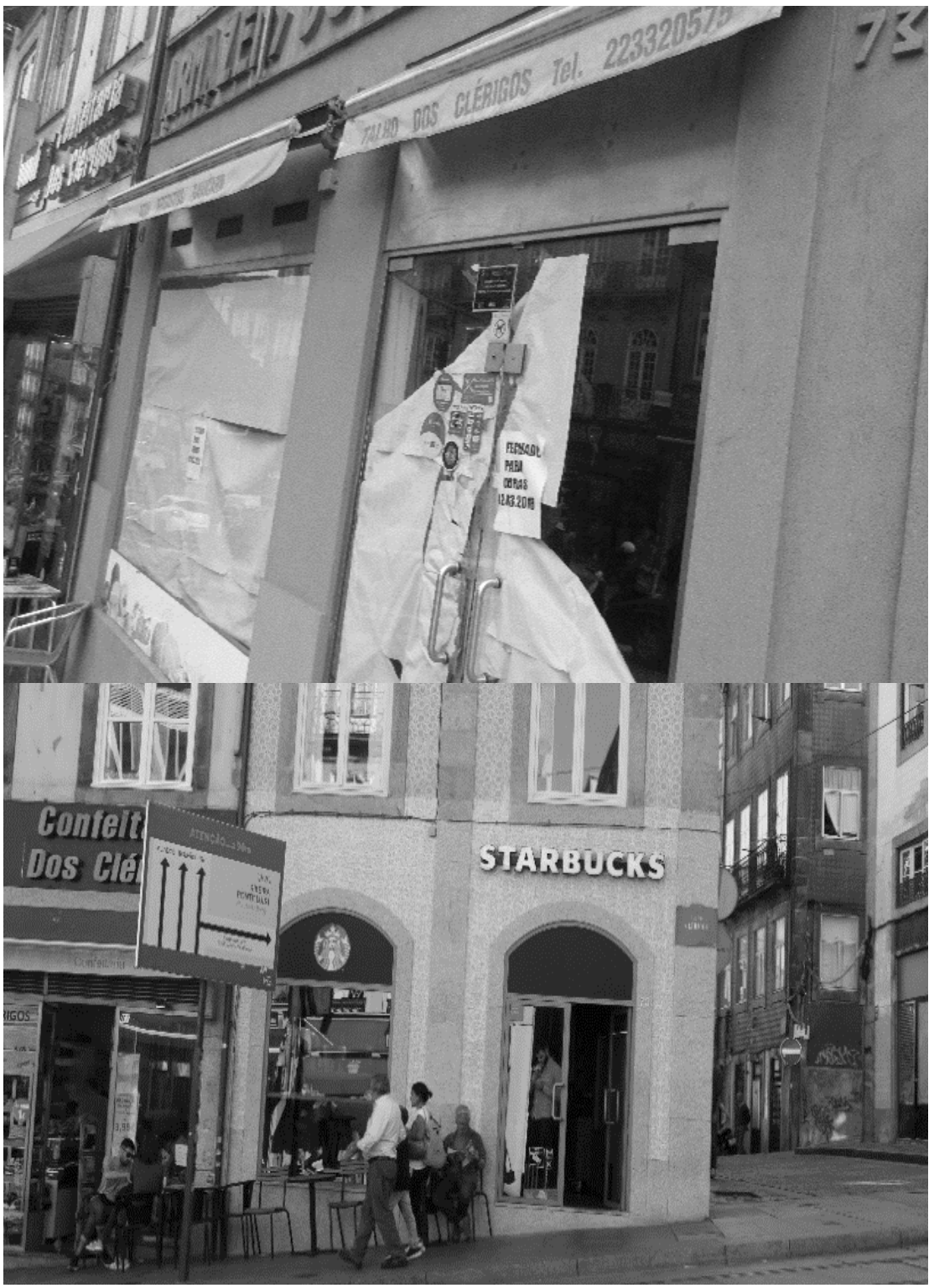

Figure 2 Towards decline (2018).

Credits. Márcia Silva

Figure 3 Standardisation (2019).

Credits. Márcia Silva 
Along with the photographs taken and experiences gained in transit through the city, the residents' voices also speak of when their neighbourhood stores were taken and the city's traditional commerce handed over to tourism companies. According to its residents, the process "mischaracterises the city, making us just one more among so many others throughout Europe", a "hollow city". As a result, some respondents admitted that they avoid certain parts of the city because of the "obvious lack of characterisation of the streets and establishments", the "complete conversion of commerce, which is now entirely directed towards tourism", filled with "trinket shops for tourists".

The next photo tells the story of Casa Oriental, an old grocer's (Figure 4) that gave way to a cannery, "a conserveira do Porto" (the Porto cannery; Figure 5).

"The residents' voices also speak of when their neighbourhood stores were taken" Márcia Silva, Rita Ribeiro and Emília Araújo

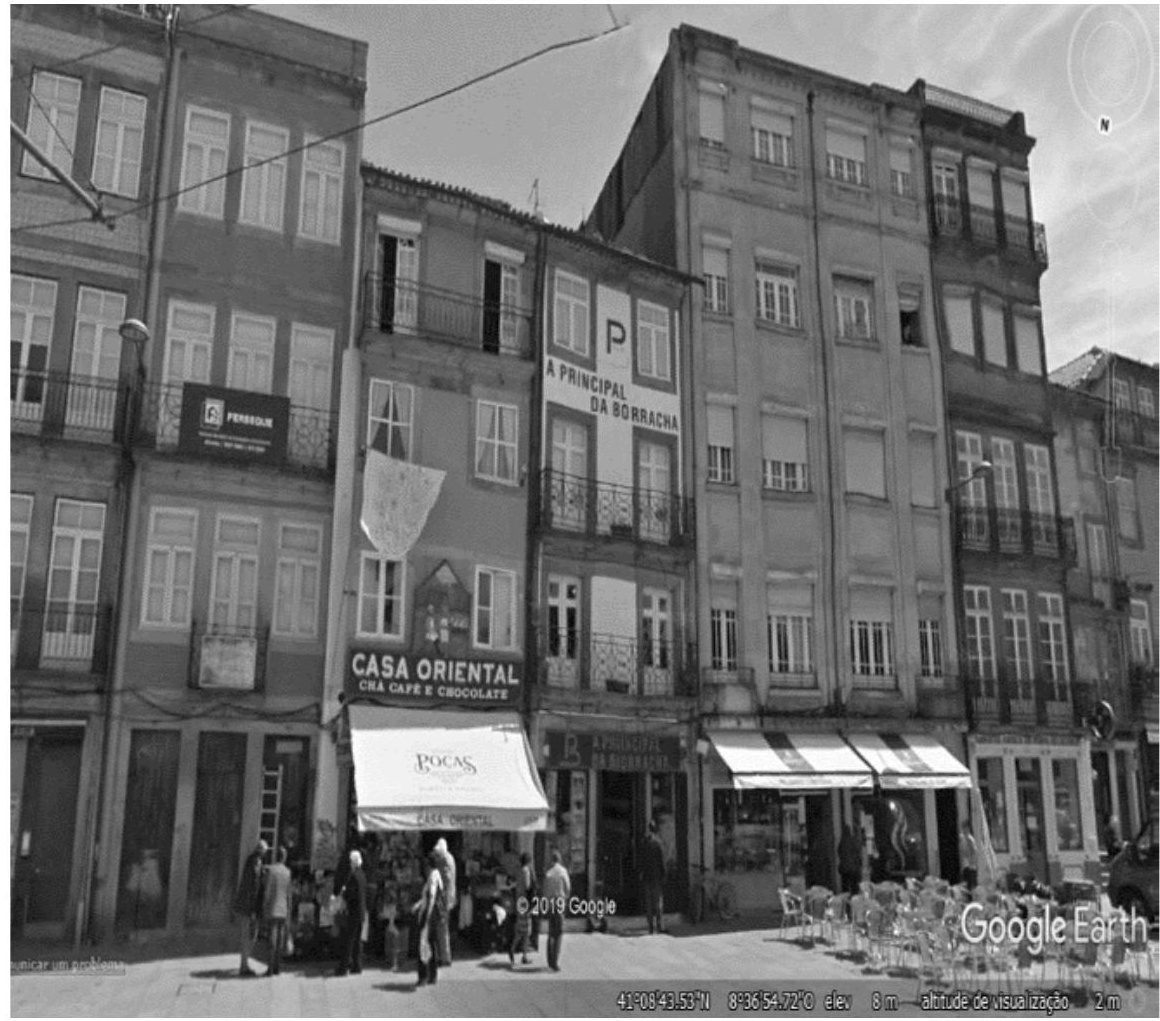

Figure 4 A Casa Oriental Shop (2009). Source. Google Maps @ 2009 Google. 


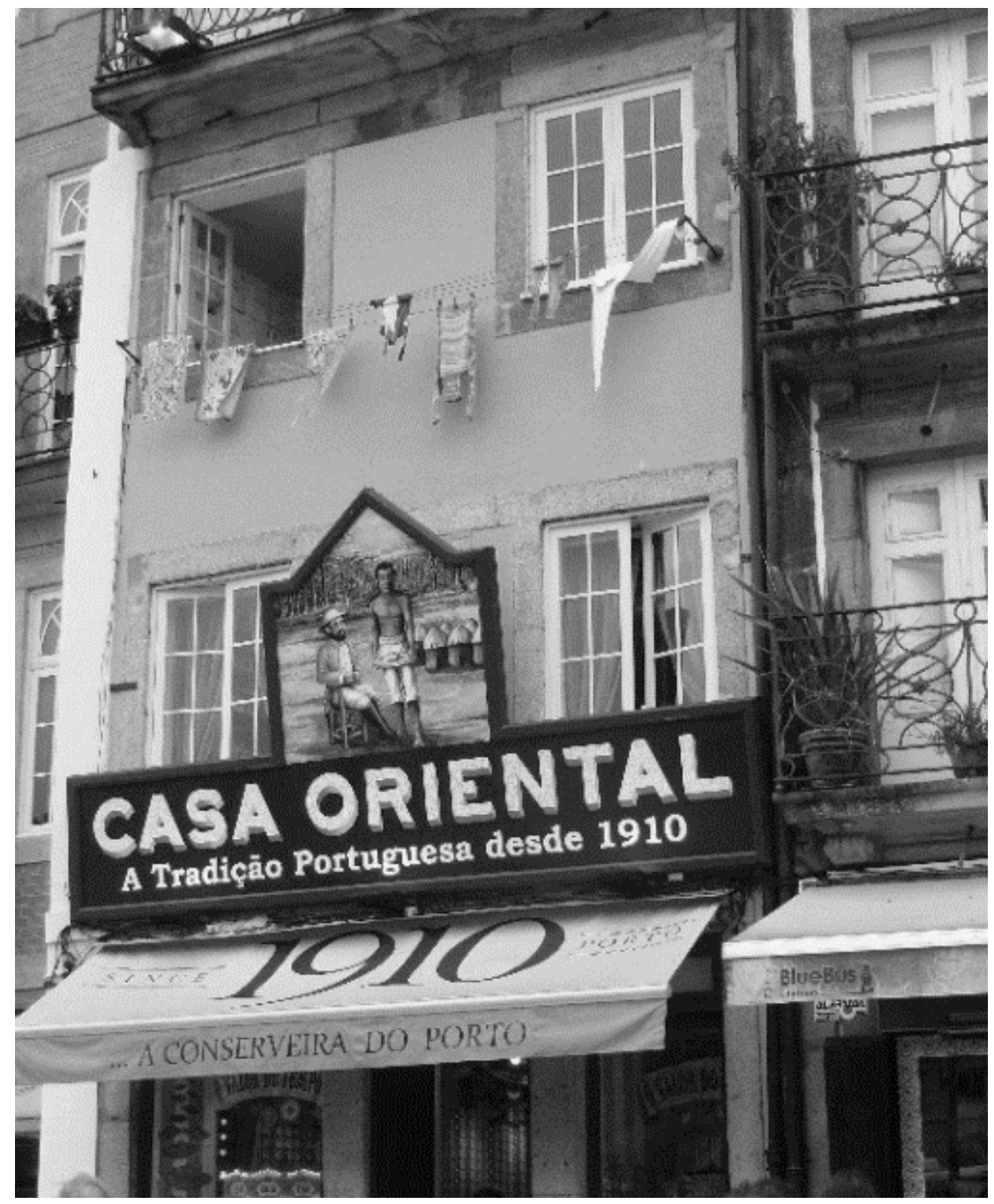

Figure 5 A Casa Oriental Shop (2019).

Credits. Márcia Silva.

In 2009, the shop's facade was marked by a sheet hung out of the window on a washing line and a shop sign stating, "Casa Oriental - Tea, coffee and chocolate", depicting the first products sold at the grocer's, in 1910.

The grocers would lose its fight against time in 2016 when it finally closed down. One of the people approached as part of the study described trying 
to rescue the memory of Casa Oriental before it was converted, expressing how difficult it is for the residents to bear witness to their city's memories being erased like that. Laura (face-to-face interview, May 31 2018), who lives in the city's historic centre, spoke nostalgically about the day the grocer's closed down. She remembers its last day being around Christmas time, and she went there to pick up the "last cod they had": "I went there for my Christmas cod to remember what it was like, to have one last memory", because "now it's just tourism. Things are very expensive, it's just for tourists".

In 2019, the experience of walking through the city was taken over, monopolised by its live performance. Instead of a sheet, the washing line bore smaller pieces of clothing, placed there on purpose as intentional decorations on the building's facade in an attempt at "typicality" and "genuineness". The message on the sign had lived on, but the lexicon and grammar were different: now the words served to invoke the tradition built at the Casa Oriental, the shop's opening year stated to mark the passing of time, exoticising it to some extent. Inside, it is entirely unrecognisable: the tea, coffee, chocolate and cod have disappeared, replaced with racing time encapsulated in cans, the same ones that can be found sold in every tourist city across the country.

\section{"Residents distance themselves from the Disneylandification of the city" \\ Márcia Silva, Rita Ribeiro and Emília Araújo}

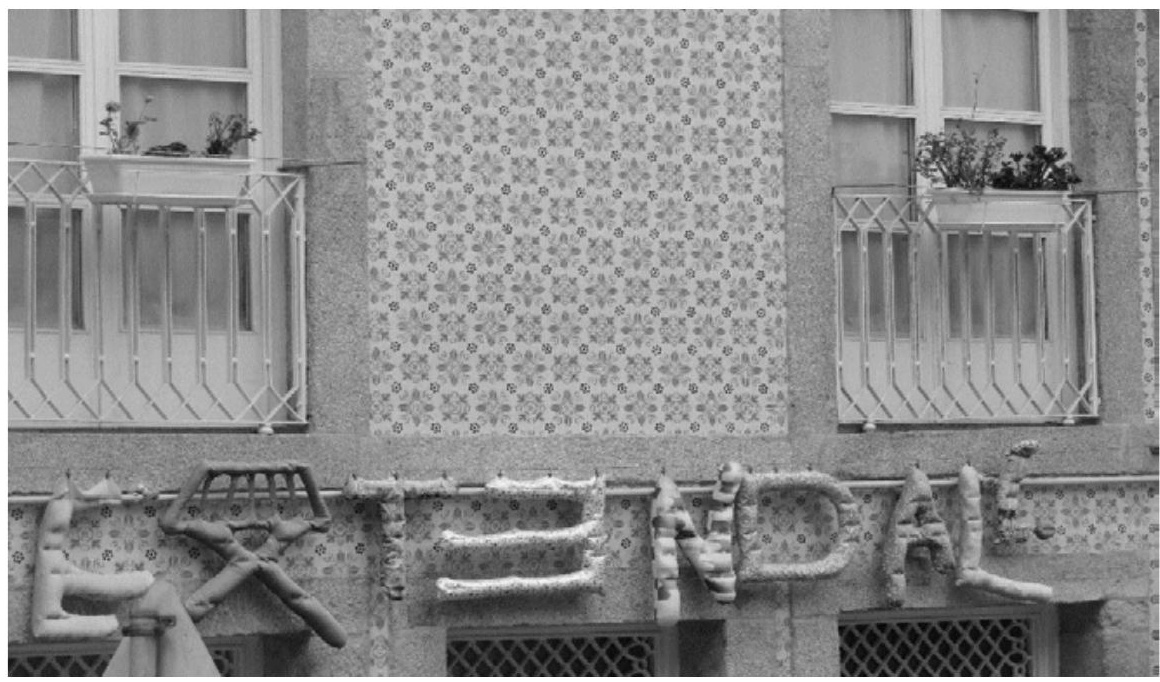

Figure 6 Clotheslines as performance pieces (2018). Credits. Márcia Silva. 


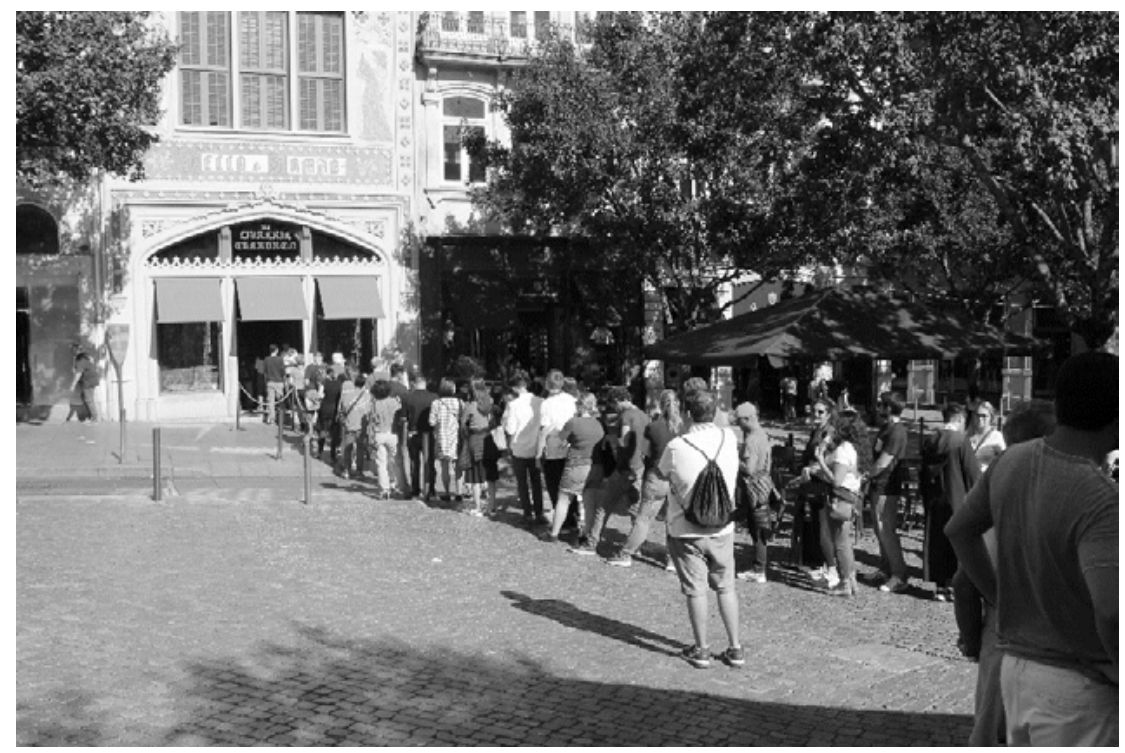

Figure 7 Lello Bookshop (2019).

Credits. Márcia Silva.

By delving further and further into the tourist city through observation, photographs or direct contact with its residents, the existence of a strange city marked by "spaces of representation" (Richards \& Wilson, 2006) is intensified. It stimulates performances, ready to create the illusion of time spent in the fleeting time remaining as a result of a growing "symbolic economy" in a simulated universe where everything seems real and where nostalgia continually revives meaning and myth, as described by Baudrillard (1981/1991).

Residents distance themselves from the Disneylandification of the city because "[they] run the risk of becoming a circus. Things are created and experienced in an attempt to maintain a tradition for the mere purpose of proving that we have tradition" (Tiago, face-to-face interview, February 11 2020; Figure 6).

In this sense, new spaces, especially their facades, are designed to produce feelings; enchantment, amazement and admiration, mirroring the aim of conditioning how traditions are experienced and feed fantasies. According to Foucault (1967/1984), who defines them as spaces of illusion and fruition, heterotopies are proposed and nurtured. Lello Bookshop (Figure 7) is 
another example of capitalising on "another" time - staged like a museum and presenting itself as a tourist attraction.

To get into the shop, both residents and tourists have to pay for a ticket and wait in the long line that stands as persistent proof of its popularity, the model tourist attraction.

\section{Dead Porto. A City Faster Than Time}

While tourism, in general, is linked to the positive effects produced by a dynamic economy and urban rehabilitation, the perception residents have of the phenomenon presents with innumerable contradictions and heterogeneities, as noted in previous studies (Nunkoo \& Ramkissoon, 2010; Remoaldo et al., 2015; Tatoglu et al., 2002; Tichaawa \& Moyo, 2019). The tourist era means a whirlwind of city "clean-ups" of its evils and diversions, such as drugs, prostitution and the like, which look bad to tourists, as well as any buildings not yet touched by renovation. Vacant spaces are resurrected, and the city itself is forced to fight time itself. However, in its speediness, tourism diverts the city from its timeline, neutralising essences and life

\section{"Images that oppose} the "Porto." brand can be seen throughout the city"

Márcia Silva, Rita Ribeiro and Emília Araújo

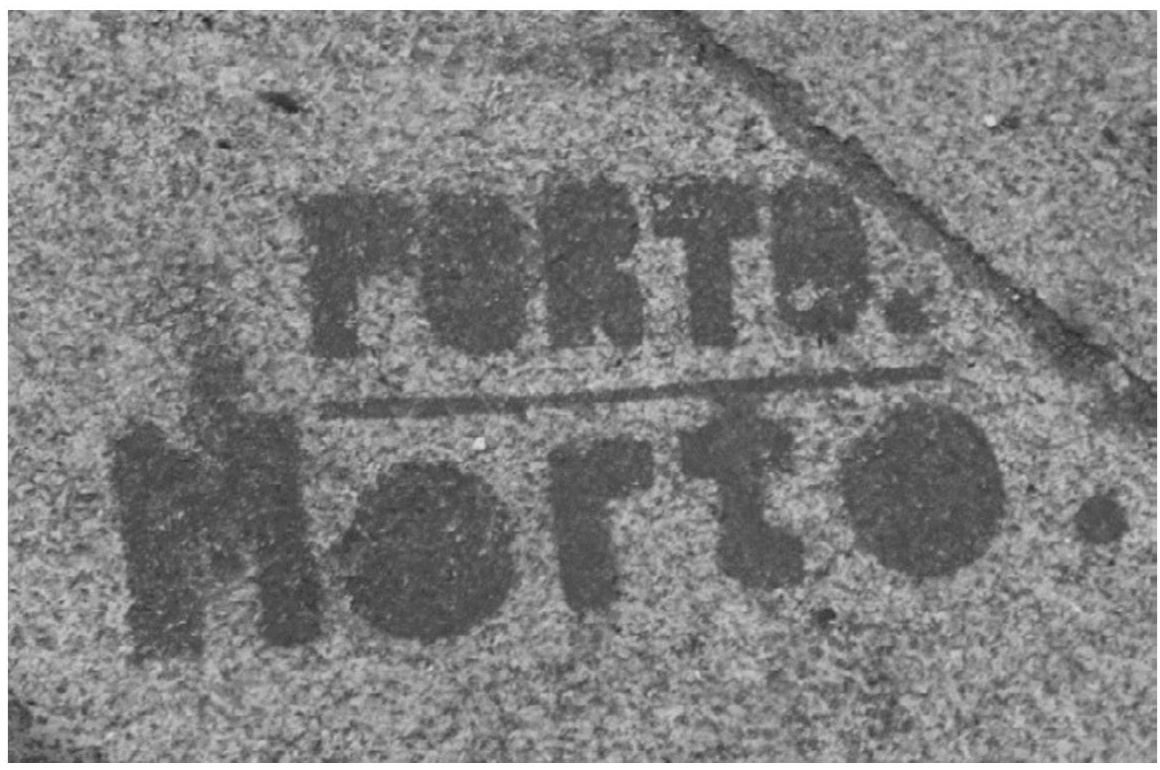

Figure 8 Morto. (2019).

Credits. Márcia Silva. 


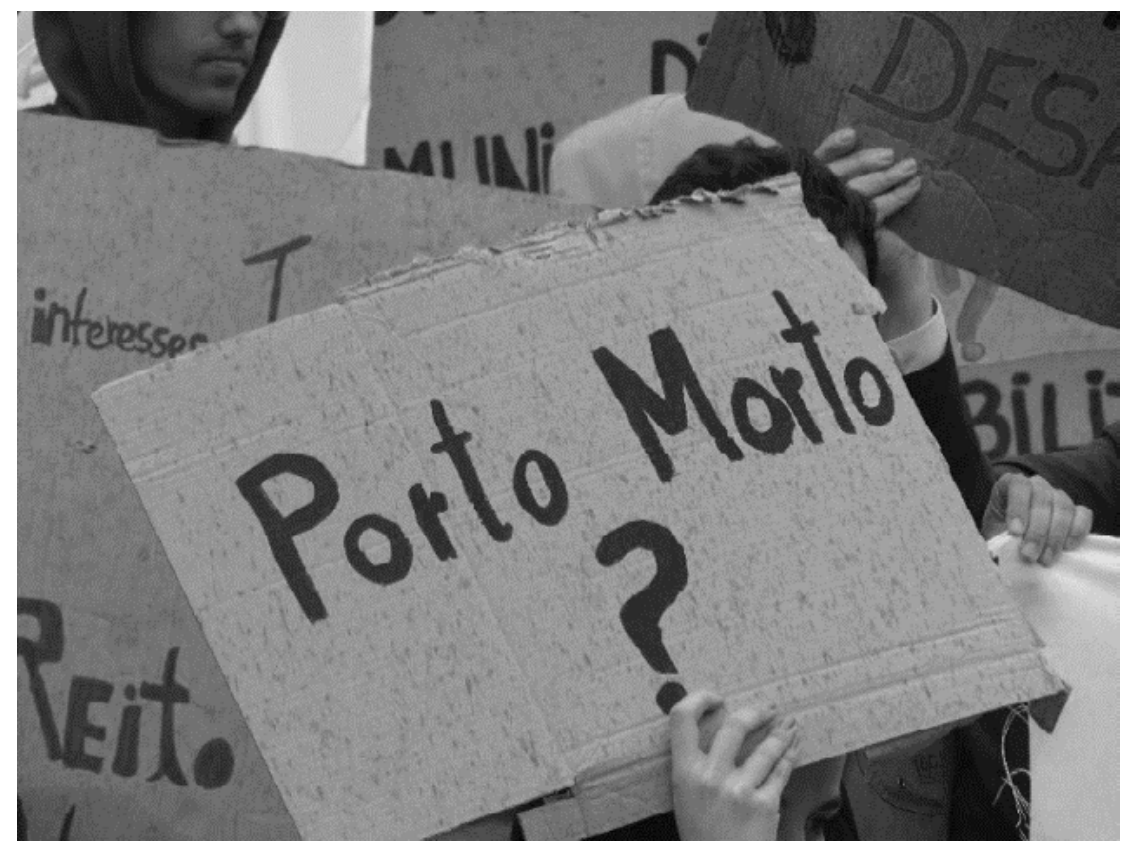

Figure 9 Is Porto dead? (2019).

Credits. Márcia Silva.

itself; it kills all of it by employing the sped-up time experienced by people who move about without stopping, making contact or coexisting. Margarida (face-to-face interview, November 5 2019) says there may be many people in the city now, but its life is gone because people wander, but they do not walk, they have no purpose, no urgency making them run to catch the bus. Instead, every person is conditioned, equal, standardised, experiencing the repetitive reflex of tourist routes through the city. The city sees its original frenzy die, and it has all changed a lot for Margarida.

Images that oppose the "Porto." brand, rhyming the name of the city with "Morto." (dead.), can be seen throughout the city, on walls, pavements and facades (Figure 8).

In demonstrations, residents are seen clutching posters reiterating the rhyme (Figure 9).

Although crowds now populate the city's streets, the "permanent" urban space has given way to one that is "temporary", the speed of daily life in 
the city having been altered, converted into a transitional space people only experience in passing, at breakneck speed. Fernando Matos Rodrigues (2021) expressed this idea in an article published in the newspaper Sol, "how was it possible to destroy a city in such a short space of time? These last few years have been of hammering, bringing down houses, memories, people, families, economies dating back centuries" (para. 8). Because of how tourism and tourists dominate time, residents create new routines, employing other times and spaces in which to have their own experiences of a city they do not want to consume, but "live in", even if it means avoiding the centre at night, walking through it in the morning instead.

\section{The Fracturing: A City on Hold}

Information collected before the COVID-19 pandemic pointed to a particular concern felt among residents as to the city's future. Residents confided that they feared the "streets would become ghost-streets" (Luísa, interview, May 17 2018) and that there is a "lack of sustainability of the model used (too much is invested in tourism thinking about its implications and consequences in the medium and long term)". As a result, "people are moving away from the centre", and the "essence of Porto" is lost. After all, as stated by Margarida (face-to-face interview, November 5 2019):

these people [the residents] disappeared, they moved to other places, other locations, and now the concern is what will happen when this tourism boom really disappears, what will happen to the areas now occupied by them [tourists], reserved for tourist accommodation. The former residents have changed their ways, and they won't go back to where they started.

The pandemic has intensified and clarified perceptions of tourism in Porto, leaving deep marks on the city and communities, whose times and lives have changed due to the influence of tourism's own time. In this sense, the expression "Porto is dead" gains a new perspective regarding the COVID-19 pandemic. Tourist numbers have decreased, and even in periods when lockdown has been lifted, the city has been empty, as if forecasting the post-tourism "ghost town" to come.

That can be seen on Avenida D. Afonso Henriques, which leads up to Porto Cathedral and the Ribeira neighbourhood, where tour buses would often park (Figure 10), leading to thousands of people, primarily tourists, converging here. 


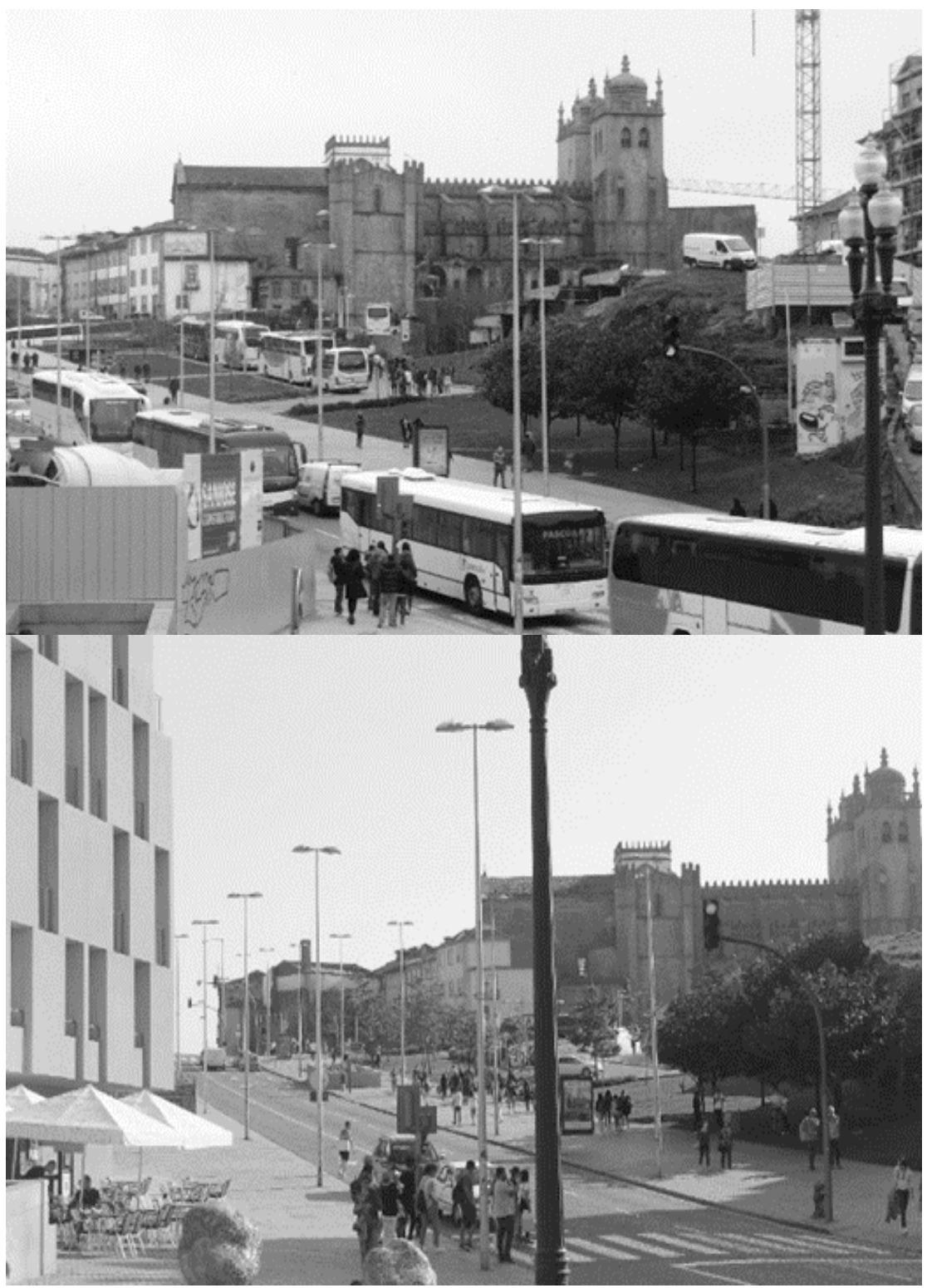

Figure 10 The city “inhabited” by tourism (2018). Credits. Márcia Silva.

Figure 11 The city uninhabited by tourism (2020). Credits. Márcia Silva. 


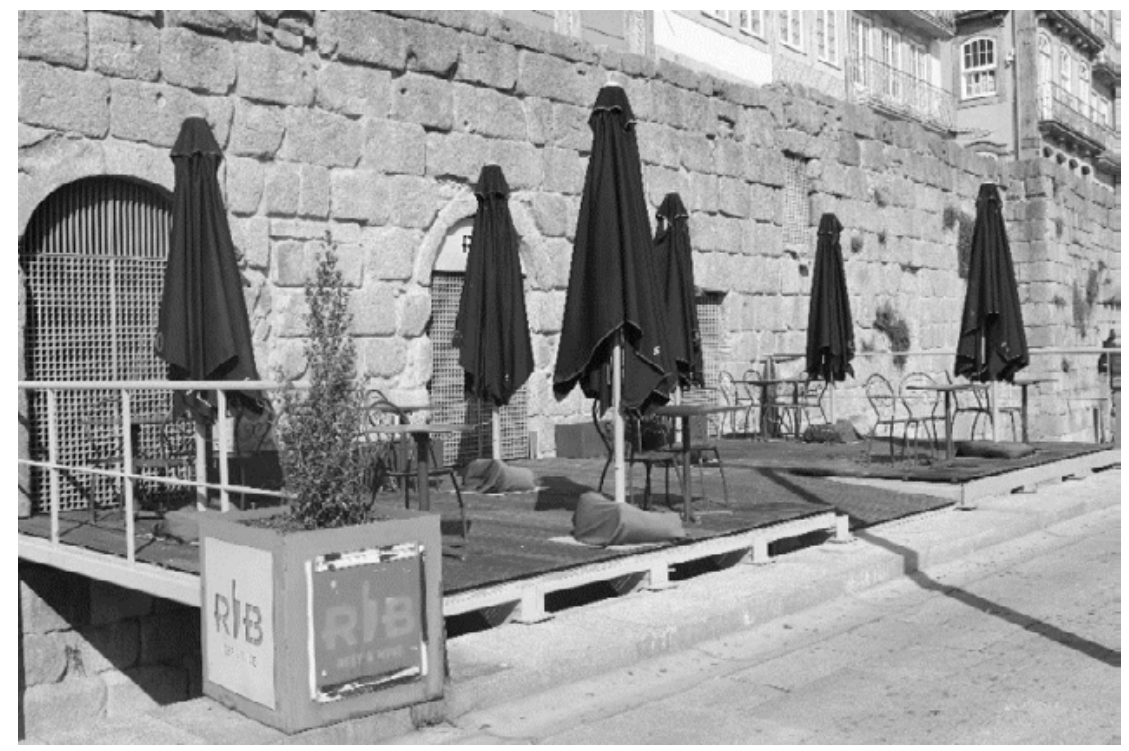

Figure 12 Ribeira on hold (2020).

Credits. Márcia Silva.

During the pandemic in October 2020 (Figure 11), there were no buses here, and as a result, no tourists.

Along with a dramatic reduction in the number of tourists, the streets are empty, the cafés and restaurants with outdoor seating areas dotted around the city closing down or barely surviving on the few tourists and residents left. One of the cases observed is down by the river itself, a once-bustling location with outdoor seating areas filled to the brim with people vying for a view over the Douro River. In the picture (Figure 12), the seating areas are closed, umbrellas are folded, and chairs lie in wait.

The pandemic paused the city: the flow of people, residents and visitors, cultural activities, and economic prosperity. However, the tourist era has not come to an end just yet; we have reached the interval, with events placed on hold, waiting expectantly for normality to return. The city has been put in neutral. Cities are now revealing the effect of an absence of people, the very same people they had given themselves up to in previous years, like never before. The visible effects felt are corroborated by numbers ${ }^{2}$ (Instituto 
Nacional de Estatística, 2020), the pandemic highlighting the fragile nature of tourist attractions based on the capitalistic over-exploitation of spaces (European Commission, 2018) when faced with a catastrophe (such as this one) that affects mobility and personal interactions (Gámez et al. 2012; Pforr \& Hosie, 2008).

Papers written on tourism and the pandemic have grown exponentially in the last year (Foo et al., 2020; Karabulut et al., 2020; Korinth \& Ranasinghe, 2020; Qiu et al., 2020; Uğur \& Akbıyık, 2020), converging towards revealing the vulnerability brought to places and populations when they become over-reliant on jobs and an economy linked to tourism (Benjamin et al., 2020). Having pressed pause on geographical mobility, the effects of the catastrophe have spread to all kinds of operations built around short-term profits in cities with vast cultural wealth. The outlook is bleak for airlines, hotels (Foo et al., 2020) and local accommodation. Like other cities, from San Francisco to Toronto, Porto's empty streets and hotels await a severe crash of the market built around the tourist era (Schaal, 2020).

\section{Concluding Note}

This text has briefly assessed the tourist era in Porto and its effects on things, spaces and the experienced time of the city and its inhabitants.

Harvey $(2008,2013)$ explains that capital-driven cities easily condemn their time to the short-term goals of surplus-value. They throw residents out, dress themselves up attractively and are purposely modernised for outsiders and foreigners - whether traders, business people or tourists. This city is eager to meet their immediate needs, providing an escape from routines and intense but fleeting sensory experiences. Much remains to be studied about how cities, their inhabitants, and policymakers conceive, interpret and value the collective time within a city and the heritage accumulated and reproduced within it in the form of "experiences" (Koselleck, 2014).

Therefore, two main concepts were demonstrated on this short journey through Porto, particularly since 2017, when this photographic repository of the city began. On the one hand, structural ideas were conveyed through the comprehensive nature of sociology, especially those inherited from Simmel and Lefebvre. They see everyday space and time as dynamic "structures" of meaning, experience and constant relocation of subjects at various levels of time. On the other, this journey has demonstrated how the experience of an observer, equipped with solid proof in the shape of photography 
and narratives, can lead from case to case and street to street, in an observation of how tourism and tourist times can be less favourable to time experienced by people and that employed by social and economic projects aiming at rapid tourist conversions. This conclusion is a common thread through studies in tourism, leading to discussions about (un)sustainability. However, the pandemic has made the matter ever more pressing, and the resulting future is starting to materialise in terms of experiential tourism, mobility and interaction.

Translation: Janela Redonda, Lda.

\section{Acknowledgements}

This work is financed by national funds within the scope of the "FESTIVITY

- Festivity, cultural heritage and community sustainability. Research and communication: the Bugiada e Mouriscada de Sobrado case" project, ref. PTDC/COM-CSS/31975/2017. This work is also supported by national funds through FCT - Fundação para a Ciência e a Tecnologia, I.P., under project UIDB/00736/2020 (base funding) and UIDP/00736/2020 (programmatic funding).

\section{References}

Aires, E. (2017). Porto. Manual de identidade. Câmara Municipal do Porto. https://www.cm-porto. pt/files/uploads/cms/cmp/7/files/21/01-manual-14-digital-2017.pdf

Agar, M. (1985). Speaking of ethnography. SAGE.

Amir, S., Osman, M., Bachok, S., \& Ibrahim, M. (2014). Understanding tourists' profile and preference of tourists' destination choice: A case study in Melaka world heritage city. Journal of the Malaysian Institute of Planners, 3, 81-94.

Araújo, E. (2020). Tiempo, sociedad y culturas: Una aproximación teórica y metodológica. In J. Caride, M. Caballo, \& R. Gradaílle (Eds.), Tiempos, educación y ocio en una sociedad de redes (pp. 15-30). Octaedro. https://doi.org/10.36006/16264-01

Bachelard, G. (2005). A poética do espaço (A. da C. Leal \& L. do V. S. Leal, Trans.). Martins Fontes. (Original work published 1958)

Baptista, L., \& Pujadas, J. (2000). Confronto e entreposição: Os efeitos da metropolização na vida das cidades. Forum Sociológico, 3/4, 293-308. 
Baptista, L., Nofre, J., \& Jorge, M. (2018). Mobilidade, cidade e turismo: Pistas para analisar as transformações em curso no centro histórico de Lisboa. Sociologia: Revista da Faculdade de Letras da Universidade do Porto, 8, 14-32. https://doi.org/10.21747/08723419/soctem2018a1

Baudrillard, J. (1991). Simulacros e simulação (M.J. da C. Pereira, Trans.). Relógio d’Água. (Original work published 1981)

Bauman, Z. (1999). Globalização: As consequências humanas (M. Penchel, Trans.). Jorge Zahar. (Original work published 1998)

Bauman, Z. (2006). Confiança e medo na cidade (M. S. Pereira, Trans.). Relógio d’Água. (Original work published 2003)

Bauman, Z. (2007). Tempos líquidos (C. A. Medeiros, Trans.). Jorge Zahar. (Original work published 2006)

Bauman, Z. (2007). A vida fragmentada - Ensaios sobre a moral pós-moderna. Relógio D’Água. (Original work published 1995)

Bauman, Z. (2008). A vida para o consumo - A transformação das pessoas em mercadorias (C. A. Medeiros, Trans.). Jorge Zahar. (Original work published 2007)

Benjamin, S., Dillette, A., \& Alderman, D. (2020). “We can't return to normal”: Committing to tourism equity in the post-pandemic age. Tourism Geographies, 22(3), 476-483. https://doi.org /10.1080/14616688.2020.1759130

Boavida-Portugal, L., \& Kastenholz, E. (2017). Paradigmas territoriais dos destinos turísticos em Portugal: $\mathrm{O}$ caso das áreas costeiras e áreas urbanas históricas. In F. Silva \& J. Umbelino (Eds.), Planeamento e desenvolvimento turístico (pp. 393-408). LIDEL Edições.

Bruner, E. (1991). Transformation of self in tourism. Annals of Tourism Research, 18(2), 238-250. https://doi.org/10.1016/0160-7383(91)90007-X

Certeau, M. de. (1994). A invenção do cotidiano: Artes de fazer (E. F. Alves, Trans.). Vozes. (Original work published 1990)

Cohen, E. (1984). The sociology of tourism: Approaches, issues, and findings. Annual Review of Sociology, 10, 373-392. https://doi.org/10.1146/annurev.so.10.080184.002105

Cohen, E. (2001). The sociology of tourism: Approaches, issues, and findings. In Y.Apostolopoulos, S. Leivadi, \& A. Yiannakis (Eds.), The sociology of tourism. Theoretical and empirical investigations (pp. 51-71). Routledge.

Collins, B. (2018). Putting culture on the map: Media discourse and the urban growth machine in Koreatown, Los Angeles. Urban Affairs Review, 56(1), 254-288. https://doi. org/10.1177/1078087418762505

Costa, C. (2018, abril). Estratégias de desenvolvimento sustentável para o turismo cultural e patrimonial. 0 caso do turismo urbano [Communication]. Conferência Património, Turismo e Desenvolvimento Sustentável, Porto, Portugal. 
Elias, N., \& Dunning, E. (1992). A busca da excitação (M. M. A. e Silva, Trans.). Difel. (Original work published 1985)

European Commission. (2018, April 17). Rethinking tourism - From vulnerability to resilience. https://ec.europa.eu/jrc/en/news/rethinking-tourism-vulnerability-resilience

Featherstone, M. (2007). Consumer culture and postmodernism. Sage publications.

Fernandes, J. (2011a). Area based initiatives and urban dynamics: The case of Porto city centre. Urban Research \& Practice, 4, 285-307. https://doi.org/10.1080/17535069.2011.616747

Fernandes, J. (2011b). Centro histórico e urbanismo: Questões, reflexões e inquietações, a propósito do Porto. In M. Rocha (Ed.), Atas do seminário Centros Históricos: Passado e Presente (pp. 12-25). Universidade do Porto.

Ferro, L. (2005). Ao encontro da Sociologia Visual. Sociologia: Revista da Faculdade de Letras da Universidade do Porto, (15), 373-398. https://doi.org/10.13140/2.1.2534.4801

Flick, U. (2002). Qualitative research - State of the art. Social Science Information, 41, 5-24. https://doi.org/10.1177/0539018402041001001

Foo, L., Chin, M., Tan, K., \& Phuah, K. (2020). The impact of covid-19 on tourism industry in Malaysia. Current Issues in Tourism, 24(19), 2735-2739. https://doi.org/10.1080/13683500.20 20.1777951

Fortuna, C. (1999). Identidades, percursos, paisagens culturais - Estudos sociológicos de cultura urbana. Celta Editora.

Fortuna, C. (2009). Cidade e urbanidade. In C. Fortuna \& R. Leite (Eds.), Plural de cidade: Novos léxicos urbanos (pp. 83-98). Edições Almedina.

Foucault, M. (1984). Of other spaces: Utopias and heterotopias (J. Miskowiec, Trans.). Architecture Mouvement/Continuité. (Original work published 1967)

Gámez, A., Ivanova, A., \& Campiranon, K. (2012). Tourism, vulnerability, and economic crisis within APEC: Responses from international destinations - Phuket, Thailand and Los Cabos, Mexico. Sustainable Tourism, 161, 91-101. https://doi.org/10.2495/ST120081

Harvey, D. (2001). Heritage pasts and heritage presents: temporality, meaning and the scope of heritage studies. International Journal of Heritage Studies, 7, 319-338. https://doi. org/10.1080/13581650120105534

Harvey, D. (2003). The right to the city. International Journal of Urban and Regional Research, 27(4), 939-941. https://doi.org/10.1111/j.0309-1317.2003.00492.x

Harvey, D. (2008). The right to the city. New Left Review, 53, 23-40.

Harvey, D. (2013). Rebel cities: From the right to the city to the urban revolution. Verso.

Harvey, D. (2016, November 14). Cultura y ciudad: El reto del turismo. CCCB. https://www.cccb. org/es/multimedia/videos/cultura-y-ciudad-el-reto-del-turismo/225261\# 
Heng, T. (2017). Visual methods in the field photography for the social sciences. New Routledge.

Hoffman, L. (2003). The marketing of diversity in the inner city: Tourism and regulation in Harlem. International Journal of Urban and Regional Research, 27(2), 286-299. https://doi. org/10.1111/1468-2427.00448

Instituto Nacional de Estatística. (2020, August 14). Atividade turística manteve forte redução em junho, mas menos intensa que em maio devido ao turismo de residentes - junho de 2020. https://www.ine.pt/xportal/xmain?xpid=INE\&xpgid=ine_destaques\&DESTAQUESdest_ boui $=415204323 \&$ DESTAQUESmodo $=2$

Jacques, P. (2003). Património cultural urbano: Espetáculo contemporâneo? Revista de Urbanismo e Arquitetura, 6(1), 32-39.

Karabulut, G., Bilgin, M., Demir, E., \& Doker, A. (2020). How pandemics affect tourism: International evidence. Annals of Tourism Research, 84, 1-5. https://doi.org/10.1016/j. annals.2020.102991

Korinth, B., \& Ranasinghe, R. (2020). Covid-19 pandemic's impact on tourism in Poland in March 2020. GeoJournal of Tourism and Geosites, 31(3), 987-990. https://doi.org/10.30892/ gtg.31308-531

Koselleck, R. (2014). Estratos do tempo - Estudos sobre história (M. Hediger, Trans.). Contraponto. (Original work published 2000)

Law, C. (1992). Urban tourism and its contribution to economic regeneration. Urban Studies, 29(3/4), 599-618. https://doi.org/10.1080/00420989220080581

Lefebvre, H. (1986). La production de l'espace. Anthropos.

Lefebvre, H. (2003). A revolução urbana (S. Martins, Trans.). Editora UFMG. (Original work published 1970)

Lipovetsky, G., \& Charles, S. (2004). Les temps hypermodernes. Editions Grasset.

Marujo, N. (2016). Turismo, turistas e experiências. Abordagens teóricas. Revista TURyDES Turismo y Desarrollo Local, 9(20), 1-13.

MacCannell, D. (2020). A economia moral do turismo. Revista Lusófona de Estudos Culturais, 7(1), 21-38. https://doi.org/10.21814/rlec.2211

Nunkoo, R., \& Ramkissoon, H. (2010). Small island urban tourism: A residents' perspective. Current Issues in Tourism, 13(1), 37-60. https://doi.org/10.1080/13683500802499414

Pais, J. M. (2010). Lufa-lufa quotidiana - Ensaios sobre cidade, cultura e vida urbana. ICS.

Pavel, F. (2017). Turismo e mercantilização da cidade. Espaços vividos e espaços construídos: estudos sobre a cidade, 1(5), 21-28.

Peixoto, P. (2003). Centros históricos e sustentabilidade cultural das cidades. Sociologia: Revista da Faculdade de Letras da Universidade do Porto, 13, 211-226. 
Pereira, G. (2016). Vinte anos depois... In A. Domingues, G. Pereiro, M. Carvalho, C. Mesquita, \& C. Dale (Eds.), Porto património mundial (pp. 33-36). Imprensa Nacional da Casa da Moeda.

Pforr, C., \& Hosie, P. (2008). Crisis management in tourism - Preparing for recovery. Journal of Travel \& Tourism Marketing, 23(2-4), 249-264. https://doi.org/10.1300/J073v23n02_19

Pires, H. (2008). A publicidade exterior e uma nova «cultura de superfície». Por entre a paisagem urbana, à deriva... In M. Martins, \& M. Pinto (Eds.), Comunicação e cidadania - Livro de atas do $V$ Congresso da Associação Portuguesa de Ciências da Comunicação (pp. 760-775). Centro de Estudos de Comunicação e Sociedade.

Pires, H. (2014). As ruas da cidade e os tempos de crise: Exercício de leitura. In E. Araújo, E. Duque, M. Franch, \& J. Durán (Eds.). Tempos sociais e o mundo contemporâneo - As crises, as fases e as ruturas (pp. 104-142). Centro de Estudos de Comunicação e Sociedade. http://hdl.handle. net/1822/38998

Qiu, R., Park, J., Li, S., \& Song, H. (2020). Social costs of tourism during the covid-19 pandemic. Annals of Tourism Research, 84,1-14. https://doi.org/10.1016/j.annals.2020.102994

Ramires, A., Brandão, F., \& Sousa, A. (2016). Motivation-based cluster analysis of international tourists visiting a World Heritage City: The case of Porto, Portugal. Journal of Destination Marketing \& Management, 8, 49-60. https://doi.org/10.1016/j.jdmm.2016.12.001

Remoaldo, P., Duque, E., \& Ribeiro, J. (2015). The environmental impacts of hosting the "2012 Guimarães European capital of culture" as perceived by the local community. Ambiente $y$ Desarrollo, 19(36), 25-38. https://doi.org/10.11144/Javeriana.ayd19-36.eing

Richards, G., \& Wilson, J. (2006). Developing creativity in tourist experiences: A solution to the serial reproduction of culture? Tourism Management, 27(6), 1209-1223. https://doi. org/10.1016/j.tourman.2005.06.002

Rodrigues, F. M. (2021, January 16). Quero o meu Porto de volta! Jornal SOL. https://sol.sapo.pt/ artigo/721656/quero-o-meu-porto-de-volta-

Santos, J. (2007). Turismo e transfigurações culturais. Tourism \& Management Studies, 3, 109-124.

Schaal, D. (2020, March 20). Short-term rental firms face backlash over sharply different coronavirus cancellation policies. Skift. https://skift.com/2020/03/20/short-term-rental-firmsface-backlash-over-sharply-different-coronavirus-cancellation-policies/

Silva, E. (2000). Património e identidade: Os desafios do turismo cultural. Antropológicas, (4), 217-224.

Simmel, G. (1997). A metrópole e a vida do espírito (C. Fortuna, Trans.). In C. Fortuna (Ed.), Cidade, cultura e globalização - Ensaios de sociologia (pp. 31-43). Editora Celta.

Smith, S. (2017). Practical tourism research. CABI. 
Tatoglu, E., Erdal, F., Ozgur, H., \& Azakli, S. (2002). Resident attitudes toward tourism impacts: The case of Kusadasi in Turkey. International Journal of Hospitality \& Tourism Administration, 3(3), 79-100. https://doi.org/10.1300/J149v03n03_07

Tichaawa, T., \& Moyo, S. (2019). Urban resident perceptions of the impacts of tourism development in Zimbabwe. Bulletin of Geography, 43(43), 25-44. https://doi.org/10.2478/bog2019-0002

Torre, E., \& Ferro, L. (2016). O Porto sentido pelo graffiti: As representações sociais dos habitantes do Porto sobre as peças de graffiti $\mathrm{d}(\mathrm{n})$ a sua cidade. Revista de Ciências Sociais, 47(1), 123-147. http://hdl.handle.net/10071/12944

Uğur, N., \& Akbıyık, A. (2020). Impacts of COVID-19 on global tourism industry: A crossregional comparison. Tourism Management Perspectives, 36, 1-13. https://doi.org/10.1016/j. tmp.2020.100744

Urry, J. (1994). Cultural change and contemporary tourism. Leisure Studies, 13, 233-238.

Urry, J. (1996). O olhar do turista: Lazer e viagens nas sociedades contemporâneas (C. E. M. Moura, Trans.). Studio Nobel. (Original work published 1990)

Urry, J. (2002). The tourist gaze. Sage Publications.

Urry, J. (2011). City life and the senses. In G. Bridge \& S. Watson (Eds.), The new Blackwell companion to the city (pp. 388-397). Wiley-Blackwell. https://doi.org/10.1002/9781444395105.ch30

Urry, J., \& Crawshaw, C. (1995). Turismo e consumo visual (Â. M. Moreira, Trans.). Revista Crítica de Ciências Sociais, (43), 47-68.

Wall, G., \& Mathieson, A. (2006). Tourism: Change, impacts and opportunities. Pearson Education. Zukin, S. (1995). The cultures of cities. Blackwell. 